\title{
IMPLEMENTATION OF ISLAMIC CRIMINAL LAW IN INDONESIA: TA ZIIR PUNISHMENT AS A SOLUTION?
}

\author{
Topo Santoso*
}

\begin{abstract}
This article deals with the recent development of Islamic criminal law in Indonesia, particularly ta zìr crime. The application of ta'zir crime accomodates many different groups because ta'zīr is part of Islamic criminal law (supported by Sharīah proponents), and the modified nature of ta'zir punishment is potentially acceptable to the Indonesian people. However, there is still a lot of criticism concerning its application and in practice, there is a sort of compromise and moderation, in a form of "inconsistent application of Islamic criminal law" or "incomprehensive implementation of Islamic criminal law." The punishment should be adapted according to the people's tolerance and acceptance. People may tolerate imprisonment, fine, community service order, or even whipping but not stoning. It is submitted that a kind of "mediation" or middle way adopted in implementing Islamic criminal law is by moderation or modification of its punishment. Since neither the Qur'ān nor the Hadīth is determinative of ta'zir punishment, the function of applying the
\end{abstract}

Senior Lecturer at Faculty of Law, University of Indonesia, Jakarta. 
appropriate punishmment can be left to the discretion of a judge or a ruler, thus minimising any rejection or criticism. However, from fiqh or Islamic jurisprudence, the question whether that kind of approach (to moderate the punishment) can be accepted still needs to be answered.

Keywords: Islam, Islamic Criminal Law, Ta żìr, Indonesian criminal law, punishment.

\begin{abstract}
ABSTRAK
Makalah ini meneliti perkembangan terbaru undang-undang jenayah Islam di Indonesia, terutamanya jenayah takzir. Pemakaian undangundang jenayah takzir sesuai dengan banyak kumpulan berbeza kerana takzir adalah sebahagian undang-undang jenayah Islam (disokong oleh penyokong Syariah), tambahan pula, kerana sifat boleh ubahsuai hukuman takzir berpotensi untuk diterima oleh rakyat Indonesia. Walau bagaimanapun, masih terdapat banyak kritikan berkenaan pemakaiannya dan dalam amalan, terdapat tolak ansur dan kesederhanaan, dalam bentuk "pemakaian tak konsisten undang-undang jenayah Islam" atau "pelaksanaan tak menyeluruh undang-undang jenayah Islam”. Hukuman perlu disesuaikan mengikut toleransi dan penerimaan rakyat. Contohnya pemenjaraan, denda, perintah khidmat masyarakat, malah sebatan boleh diterima, tetapi rejam tidak. Dihujahkan bahawa satu bentuk "mediasi" atau pendekatan jalan tengah dalam pelaksanaan undang-undang jenayah Islam adalah dengan kesederhanaan atau pengubahsuaian hukumannya. Disebabkan al-Qur'ān dan Hadis tidak menetapkan hukuman takzir, fungsi memakai hukuman yang sesuai boleh diserahkan kepada budi bicara seorang hakim atau pemerintah, dengan
\end{abstract}


demikian meminimakan sebarang penolakan atau kritikan. Walau bagaimanapun, dari perspektif fikah, persoalan sama ada pendekatan begini (untuk menyederhanakan hukuman) boleh diterima perlu dijawab.

Kata kunci: Islam, undang-undang jenayah Islam, takzir, undang-undang jenayah Indonesia, hukuman.

\section{INTRODUCTION}

This article discusses recent development of Islamic criminal law in Indonesia. Islamic law is considered as the material legal source of Indonesian national law. The role of Islamic law in private and economic matters has been formally accepted for quite a long time. Its role in criminal law, however, is still debatable and has endured many criticisms. This article describes the debate between the proponent group favouring the application of Islamic criminal law and those who are against the idea. The issue that needs to be analysed is whether Islamic criminal law can be implemented formally under the current Indonesian legal system.

Discussions on such issues can be found in "The Islamic law of apostasy and its modern applicability: a case from Sudan” (A.A. AnNa'im: 1986), "Problems in contemporary applications of Islamic criminal sanctions: the penalty for adultery in relation to women" (Abdel Salam Sidahmed: 2001), Criminal Punishment in Islamic Societies: Empirical Study of Attitudes to Criminal Sentencing in Iran (Ghaseem Ghaseemi, 2009), and Law and Practice of Islamic Hudood (Emmanuel Zafar: 2002).

The topic has also been discussed in the Indonesian context in a 2007 article entitled "Challenging the Secular State: the Islamization of Law in Modern Indonesia” by Arskal Salim. Furthermore, when discussing whether the application of Islamic criminal law is compatible with International human right standards, we may refer to Alfitri's article, "Can the Requirements of Shariah Law Regarding Criminal Punishments be interpreted in a way that is Compatible with the $\mathrm{ICCPR}^{1}$ and 
CAT?”2 in which Alfitri raises the question " Can a state impose death penalty or corporal punishments required by the Shariah law while it conflicts with the state's obligation to comply with international human rights instruments?” Alfitri argues that an approach which is able to reconcile the requirements of Sharī' ah law regarding criminal punishment and those of international human right norms is necessary. ${ }^{3}$

According to Alfitri, "the requirements of both the Islamic criminal law and the ICCPR and CAT can therefore be mediated, inter alia, by strictly adhering to the procedural and evidential requirements prescribed by the Koran which were then theorized by classical Islamic jurists. This method is expected to effectively pacify the criticisms coming from both human rights advocates and proponents of the Shariah law regarding the implementation of Islamic criminal punishments in Muslim countries that are parties to the ICCPR and CAT."

Alfitri pointed out that this approach has been practiced in Nigeria, particularly in Safiyya Husaini case and Amina Lawal case in which the two people had been sentenced to death in 2002 and 2003 for committing adultery. However, later they were each acquitted by the state appeal courts of Katsina and Sokoto. The appeal court judges dismissed the stoning punishment on the strength that proper Islamic criminal law procedures had been neglected by the lower Sharī'ah court judges. According to Alfitri, this approach would lead to the extensive application of $t a^{\prime}$ zir punishments. ${ }^{4}$

The important function of $t a{ }^{\prime} z i r$ is to provide grounds for the punishment of those who have committed Hadd crimes $^{5}$ or Qiṣās crimes ${ }^{6}$

$2 \quad$ The Convention against Torture and Other Cruel, Inhuman or Degrading Treatment or Punishment.

3 Alfitri, "Can the Requirements of Shariah Law Regarding Criminal Punishments be interpreted in a way that is Compatible with the ICCPR and CAT," in Indonesian Journal of International Law, Vol. 7 Num. 1, October 2009, pp. 100-136.

4 Ibid.

5 Offences mentioned in the Qur'ān which constitute violations of Islamic law as ordained by God (huqūq Allah), with mandatory fixed punishments (hadd, plural hudüd); these offences are: zinā (adultery and fornication/unlawful sexual intercourse), shurb al-khamr (alcoholic drinking), sariqa (theft), qadhf (the unfounded accusation of unlawful sexual intercourse), Hiräbah (armed robbery/terrorism), Qat' al-tarīq (robbery), irtidād or riddah (Apostasy), Al-Baghy (rebellion). 
or any crime against other people but cannot be sentenced with an appropriate punishment because of procedural reasons (e.g. lack of legally required evidence) or substantive criminal law reasons (the elements of Hudūd or Qișās crime are not fulfilled). ${ }^{7}$

As far as the implementation of Ta $\mathrm{z} i \mathrm{r}$ punishment is concerned, Alfitri's opinion is very relevant. The application of Ta 'zir punishment becomes a moderate way or a potential solution for Muslim countries both to implement Sharī'ah law (as directed by divine sources: the Qur'ān and the Sunnah) and to comply with international standards of human rights (such as ICCPR and CAT). This can be accomplished by strictly implementing procedural law under the Islamic criminal justice system. If the requirements prescribed by such procedural provisions cannot be

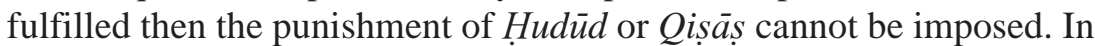
this situation, $\mathrm{Ta}$ 'zir punishment should be applied.

In practical situations, $\mathrm{Ta}{ }^{\prime} \mathrm{z} \overline{\mathrm{r}}$ crimes and $\mathrm{Ta}$ 'zìr punishment will be practiced more widely rather than Hudüd and Qișās crimes. As Peters pointed out that $\mathrm{Ta}^{\mathrm{C}} \mathrm{z} \overline{\mathrm{i}} \mathrm{r}$ is a residual category of penalties, however, in

According to Muhammad Shabbir the term Hirābah is used for crimes: armed robbery (al-hiräbah), great theft (al-sariqa) and highway robbery (qat $t^{\prime}$ al tarīq). For detailed description concerning Hudud Crimes see Mohammad Shabbir, Outlines of Criminal Law and Justice in Islam, Selangor Darul Ehsan: International Law Book Services, 2002, pp. 64-268. For a comparative account see also Rudolph Peters, Crime and Punishment in Islamic Law, Theory and Practice from the Sixteenth to the Twenty-First Century, Cambridge: Cambridge University Press, 2005, p. 7.

6 Qiṣaṣs means “equality” or “equivalent.” In Islamic criminal jurisprudence, qișas is provided for willful murder and intentionally causing injury. It is to punish the wrongdoer in the same manner as he caused wrong to the victim. Qișạs is a right and not an obligation. Islamic criminal law does not only provide right to the victim for retaliation, but also gives the right to forgive the offender. He is entitled to relinquish qișass in lieu of compensation (diyah). There are five crimes under qișās-diyah crime category: murder, voluntary or intentional killing, involuntary or accidental killing, Voluntary or intentional physical injury, and involuntary or accidental physical injury. See Mohammad Shabir, Ibid. pp. 270-282.

$7 \quad$ Rudolph Peters, op.cit., p. 66. 
practice $T a{ }^{\prime} z \bar{i} r$ is the most important heading under which punishment is administered. ${ }^{8}$

In the above context, this article pays attention to a specific crime in Islamic criminal law called Ta zìr crime as a penal means to mitigate the spread of criminal actions. The reason for the article focussing on $\mathrm{Ta}^{\prime} \mathrm{z}$ ir crime, is related to the on-going debate over application of Hudūd and Qiṣaș which may take a long time to abate with very little possibility of arriving at a common understanding due to the strong arguments raised by both the proponents and opponents. Moreover, there is a pressing need to find a solution to the Ta $z \bar{z}$ r crimes which have resulted in serious harm, mass destruction, and huge cost of life.

It is submitted that the application of Ta $z \bar{r} r$ will accomodate many different groups. The reason is that $T a{ }^{\prime} z \bar{z} r$ is part of Islamic criminal law (supported by Sharī'ah proponents), and in addition, the nature of Ta 'zir punishment is relatively accepted by Indonesian people. With regard to non Aceh society, Ta zìr crime/ punishment may use more general names, such as violation (pelanggaran). Yet, from the Islamic criminal law jurisprudence point of view, in substance such a violation is still considered as $\mathrm{Ta}^{\mathrm{C}} \mathrm{z} \overline{\mathrm{i}}$. However, since Indonesian society is pluralistic, there are still a lot of criticism concerning such an idea.

As mentioned earlier, there are many other types of crime beside Hudūd and Qișās that occur everyday, causing serious damage and harm to people (e.g. fraud, tax fraud, employment offences, environmental crimes, marketing malpractices, food offences, cybercrime, illegal logging, money laundering, and corruption). The cost of such crimes is enormous. In 1949, Sutherland described the seriousness of such crimes by the term "white collar" crimes. Conklin (1977) attempted to make a comparison between the total costs of selected conventional crimes and the total cost of white collar crimes in the U.S. The result was daunting: while the total cost of robbery, theft, larceny and car stealing was estimated at \$ 3-4 billion, selected white collar crimes, such as consumer fraud, illegal competition and deceptive practices cost an estimated amount of \$ 40 billion. In a similar note, Levi (1995) pointed out that in the United Kingdom in 1994, the total cost of burglaries was calculated to be $£ 1$ billion; at the time the report was being prepared, the Serious Fraud 
Office was dealing with cases involving the aggregate value of more than $£ 5$ billion. ${ }^{9}$

Considering these facts, do we really need to continue the neverending debate on Hudüd and Qiṣās implementation, while Ta zìr crime causes more harm and destruction? People are more concerned with Hudūd and Qișass crimes, and pay little attention to Ta 'zìr crimes. This is equivalent to people being more concerned about street crimes than white collar crimes, even though the cost of the latter is more extensive. Therefore, Islamic criminal law experts should develop Ta 'zīr offence conceptions which are more suitable to the modern context and civilization.

In Indonesia, Aceh is the only province which legally applies Islamic criminal law, mainly Ta 'zir category. In other provinces, even though the demand to implement Islamic Sharī'ah is increasing, Ta 'zīr crimes are not formally applied. Indeed, according to Islamic criminal doctrine, many criminal law provisions can be seen as Ta zìr crimes. However, the difference is clear: only Aceh officially has special statute and right to implement Islamic criminal law, and it is only Aceh that has Maḥkamah Sharī`ah whose jurisdiction covers criminal matters.

Reccently, demand to apply regulations that are more accommodative of religious and moral values is increasing. ${ }^{10}$ As an illustration, we may refer to the situation in Tangerang (Banten), Indramayu (West Java), Tasikmalaya (West Java), Bulukumba (South Sulawesi), and Bima (West Nusa Tenggara). The following regulations can be cited as examples: Peraturan Daerah (Provincial Regulation) on Quranic Education in South Sulawesi, ${ }^{11}$ Municipal Regulation 2003 on Alcoholic Drink; on Zakat, Infak, and Sedekah; on Quranic Teaching for Students and Marital Couples; as well as Islamic dress. These four regulations issued in 2003 resulted in Bulukumba being eventually known as a pioneer in Islamic Sharī`ah implementation in South Sulawesi. ${ }^{12}$

$9 \quad$ Hazel Croall, Understanding White Collar Crime, Maidenhead, Berkshire: Open University Press, 2007, p. 23.

10 http://www.gatra.com/artikel.php?pil=23\&id=94078.

11 Center for the Study of Religion and Culture (CSRC) Universitas Islam Negeri (UIN) Syarif Hidayatullah, laporan penelitian yang dilakukan sepanjang tahun 2006.

12 http://www.gatra.com/artikel.php?pil=23\&id=94078. 
Regardless of the fact that most local regulations (Peraturan Daerah/Perda) are not based on Islamic criminal law or Sharī'ah, many local regulations are seen as the implementations of Islamic Sharī'ah, particularly those which entails moral obligations. This kind of regulations is regarded as offensive toward women. For example, the Tangerang municipal regulation which prohibits conduct related to prostitution was brought to the Supreme Court as a judicial review case. That petition was finally dismissed by the Supreme Court which stated that such a regulation did not violate higher law and regulation. In March 25, 2010, there was also another judicial review case decided by Indonesian Constitutional Court. In the case, the Constitutional Court dismissed the petition on Antipornography Law (Law No. 44 of 2008) which is alleged by activists as a violation of constitutional provisions (discrimination againts women) and also regarded as a Sharī' ah based regulation.

\section{ISLAMIC CRIMINAL LAW}

Islamic criminal law has been regarded as a major legal system beside common law and civil law legal tradition. There are abundant works concerning Islamic criminal law, among which are: A Modern Approach to Comparative Law (Peter De Cruz:1993), Major Legal System in the World Today (Rene David and John E.C: 1996), Introduction to Foreign Legal System (Danner and Bernal: 1994), An Introduction to Comparative Law (K. Zweigert \& H. Kotz Third Edition: 1998), and Comparative Criminal Justice Systems (Philip L. Reichel: 2004).

In Islamic law, crime (jarimah/jināyāt) is defined as legal prohibitions prescribed by God, and a violation to such prohibitions will result in a punishment determined by God. The prohibitions may include doing a forbidden act (the commission of an act) or omission of a permitted act. According to Audah, in Islamic law the commission or omission of an act is not considered a crime until a punishment is prescribed by Shariah. ${ }^{13}$

From the above definition, the concept of crime in Islamic law and western law appears to be similar. However, there are several

13 Audah, Abdul Qadir, Criminal Law of Islam, Karachi, International Islamic Publishers, 1987, p. 72. 
theoretical and practical differences between the two legal systems, particularly in terms of the sources of law, the history and the development of the systems, their relation to morality, and the objective of the law. Islamic legal experts often use the term janāyāt for crime. Janāyāt/ jināyah refers to doing a forbidden act. It signifies the act, which is unlawful due to being injurious, carries punishment for those who commit the act, and it falls under the category of criminal offence. Jināyah covers all kinds of prohibited and injurious acts which affect human body or property or comprise any other violation. It is an act which adversely affects the rights of individuals and society and interferes with or disturbs the peace and tranquility of the state. ${ }^{14}$

Legal experts apply the term Jinäyah for all conduct which is considered illegal by Shariah and is commited against someone's life/ body, property or anything else. However, the majority of legal experts apply Jinayah for crimes againts human life/body, such as murder, manslaugter, bodily injury, physical assault or intentional abortion. ${ }^{15}$

The other term for crime is Jurm or Jarimah. The literal meaning of jurm is “to cut off”. In Islamic criminal jurisprudence, jurm means a sin, fault, crime, an offence, or an act of disobedience irrespective of the fact whether it is committed intentionally or inadvertently. This word is also used to denote unfair action and unfair earning. All actions or conduct, which are against the right path and justice fall in the category of jurm. Those who are involved in wrongdoing are called mujrim. ${ }^{16}$ Islamic criminal law strives to protect religious faith, life, property, sanctity of individual, family and senses of human beings. To achieve this objective, an effective enforcement of punishments is imperative. ${ }^{17}$

Punishment is justified in Islamic law by detterence, retribution, rehabilitation and protecting society by incapacitating the offender. Since Sharī'ah is religious law, some of the laws of punishment also have a "vertical" dimension, in which they relate to reward and punishment in the Hereafter. ${ }^{18}$

\footnotetext{
$14 \quad$ Muhammad Shabbir, op.cit., p. 8.

15 Audah, op.cit., p.73.

$16 \quad$ Muhammad Shabbir, op.cit. p.8.

17 Muhammad Shabbir, Ibid. pp. 8-9, see also Audah, op.cit., p. 74.

18 Rudolph Peters, op.cit., 30.
} 
The most widely used categories of crime and punishment in Islamic law are: Hudūd, Qișās, and Ta zìr. ${ }^{19}$ Hudüd crime is the most serious crime and its punishment is the most severe in Islamic law. It is a crime against public interest. Yet, it doesn't mean that hudūd crimes are not related to individual interest. It is mostly related to what is called Haq Allah (rights of God). The punishment for hudud crime is called hudūd whose quality and quantity are specified in the Qur'ān and the Hadìth.

According to Mohammad Ibn Ibrahim Ibn Jubair, huudūd crime comprises seven offences, namely: riddah (apostasy), al-baghy (rebellion), zina (adultery and fornication/ unlawful sexual intercourse), qadhf (the unfounded accusation of unlawful sexual intercourse), sariqah (theft), hiräbah (armed robbery/ terrorism/banditry), and shurb al khamr (drinking alcohol). ${ }^{20}$ According to Muhammad Shabbir, the term Hiräbah is used for crimes like armed robbery (al-hiräbah), theft (al-sariqah) and highway robbery (qatī al tarīq). In some authoritative sources of fiqh, these terms are used interchangeably, but taking into account the

19 The other categories are quite similar with categories in common law or civil law, with slight differences. For more detailed see Audah, op.cit., pp. 90-123. There are opinions questioning the ground of the categories into hudūd, qișasṣ, and ta 'zīr as the Qur'ān and Hadīth didn't make such categories.

20 See Mohammad Ibn Ibrahim Ibn Jubair, "Criminal Law in Islam: Basic Sources and General Principles,” dalam Tahir Mahmood (ed), Criminal Law in Islam and the Muslim World-A Comparative Perspective, Delhi: Institute of Objective Studies, 1996, hal. 54-55. See similar opinion in Safia M. Safwat, "Crime and Punishment under Various School of Shariah: A Comparative Overview,” in Mahmood., Ibid. Several scholars criticize the coverage of hudud crimes, some held that hudüd crimes consist of seven offences (sariqah, zinā, qadhf, hiräbah, shurb alkhamr, riddah, al-baghy), some scholars held that hudüd crimes consist of six offences (sariqah, zinā, qadhf, hiräbah, shurb al-khamr, riddah), while several scholars held that $h u d \bar{u} d$ crimes consist of only four offences which the prohibition and their sanctions are clearly provided in the Koran, namely sariqah, zinā, qadhf, and hirābah. See for more detailed in Mohammad Hashim Kamali, Punishment in Islamic Law, An Enquiry into the Hudūd Bill of Kelantan (Kuala Lumpur: Ilmiah Publishers, 1995). 
spirit and substance of the relevant verses dealing with hiräbah, the use of al-hiräbah is preferable. ${ }^{21}$

The next category of crime and punishment in Islamic criminal law is qișăs. Qișās crimes are those offenses that require retaliation by the victim or victim's family. They include voluntary homicide, involuntary homicide, intentional physical injury, and unintentional physical injury. This crime falls between the more serious crime, hudud, and the less serious crime, Ta 'zir. The object of this crime is based on harming the integrity of the human body, intentionaly or unintentionally. It may be called "crime against person."22

The last category of crime and punishment is $\mathrm{Ta}$ ' zir. The grounds and determination of its punishment are based on ijm $\bar{a}^{c}$ (consensus) which is related to the right of the state to criminalize every inappropriate conduct causing any physical, social, political, financial and moral harm and destruction to individual or society. ${ }^{23} \mathrm{Ta}$ 'zir crime comprises three parts: 1) hudūd or qiṣās crime which lacks certainty (subhah) or does not fulfill the requirements/ elements of hudüd or qișass, yet is regarded as ma șiah/ illegal conduct, such as attempted stealing, theft committed in a family, theft in which the stolen property does not exceed the minimum value; 2) conduct which is forbidden in the Qur'ān or Hadith but the sanction for such conduct is not prescribed, such as defamation, false witness, breaching amānah/mandate; 3) crimes determined by government or Uli al Amr in order to protect social or public order. In such a situation, the basic Islamic values or principles are taken as considerations to determine what constitutes the public good. ${ }^{24}$

It is important to note that in Islamic criminal law, all categories of crime (as long as the requirements or elements are fulfilled) should conform to the punishment prescribed for such categories. For example, the appropriate punishment for hudūd crime is hudūd punishment (not

\footnotetext{
$21 \quad$ Muhammad Shabbir, op.cit., p. 174.

22 See Nagaty Sanad, The theory of crime and criminal responsibility in Islamic Law: Saria, (Chicago: Office of International Criminal Justice, 1991). 61.

$23 \quad$ Ibid., hal. 63.

$24 \quad$ H.A. Djazuli. Fiqh Jinayah, Upaya Menanggulangi Kejahatan dalam Islam. Jakarta: Rajawali Press, 1996, pp. 13-14.
} 
qișäs or ta zïr punishment), ${ }^{25}$ the punishment for qisas crime is qișăs punishment, ${ }^{26}$ and the punishment for ta ${ }^{\text {' }} \overline{i r}$ crime is ta $z \bar{z}$ r punishment.

\section{THE DEBATE ON ISLAMIC CRIMINAL LAW IMPLEMENTATION IN INDONESIA}

There are at least three issues which can be raised in Indonesian context: firstly, whether the application of Islamic criminal law is in line with Indonesian legal system; secondly, whether Islamic criminal law contradicts the International human rights standards; and thirdly, how the implementation of such law will be carried out.

There are two different stands in determining whether the implementation of Islamic criminal law contradicts the 1945 Indonesian Constitution. The first is related to special law case in Aceh, and the second is related to the national law and regional law (outside Aceh). In the first case, Islamic criminal law is practiced in Aceh based on several statutes, while at the national level and in other provinces, Islamic criminal law cannot be enforced. Islamic law is considered by the Constitutional Court only as one of various legal sources (particularly material legal sources), and not as the only legal source in Indonesia. We can see the position of Indonesian Constitutional Court in Amrozi, Imam Samudera, and Ali Gufron case ${ }^{27}$ and in Suryani case.

In Amrozi, Imam Samudera, and Ali Gufron case (case No.21/ PUU-VI/2008), the convicted of the First Bali Bombing raised a petition to the Constitutional Court demanding to apply Islamic law method of execution by beheading, instead of execution by shooting as regulated in

25 Such as amputation of a hand for sariqah (theft); death, crucifixion, cross-amputation of the hand and foot or banishment for hiräbah (armed robbery/ terrorism/banditry); and stoning to death for adultery, one hundred lashes for fornication.

26 Retaliation, the return of life in a case of murder, or the same wound in case of physical assault and diyah (compensation or blood-money) for involuntary homicide. The punishments for qișās crimes may be waived by the victim or the surviving heirs and they can ask for financial compensation (diyah).

27 http://www.detiknews.com/read/2008/09/18/135350/1008484/10/jikadikabulkan-mk-amrozi-cs-tidak-bisa-dieksekusi-dengan-tembak 
Law No. 2/Pnps/Tahun 1964 (law concerning Method of Death Punishment). The petitioners argued that their right not to be tortured, as provided in Section 28 I(1) 1945 Constitution, was violated by the method of execution regulated in Law No. 2/Pnps/Tahun 1964.

The petitioners demanded another method of execution which was more humane. According to Islamic law which constitutes the living law in Indonesia (as the biggest Muslim country in the world), the requirement for the method of execution is ihssān al-qatl (the best mode of execution) in order to ease the death. In this case, the Constitutional Court held that "the pain experienced by the convicted is a logical consequence sticking with the death process due to the implementation of death penalty regulated by the procedural law.” Accordingly, this method of punishment does not constitute torture for the convicted. According to the Constitutional Court, all methods of execution beside shooting (such as hanging, beheading, electrocution, gas chamber, lethal injection) cause pain which varied in gradation and speed. This, according to the Court, is not a violation of Section 28 I of 1945 Constitution.

In Suryani case (Case No. 19/PUU-VI/2008), the petitioner argued that according to Islam, Muslims are obliged not only to apply private law (marital, waris, hibah, wakaf, zakat, infaq, shadaqah and muamalah) as regulated in Law No. 7 of 1989 on Religious (Islamic) Court as amended by Law. No. 3 of 2006, but also to the application of Islamic Shariah for criminal offences as dictated by Sūrah Al-Mā'idah (38) in the Qur'ân.

In this case, the Constitutional Court held that the implementation of Islamic law should relate to the sources of law. As far as the sources of law are concerned, it can be said that, Islamic law is a part of Indonesian sources of law, but not the only source since western law, other legal traditions and custom (hukum adat) are also parts of the national sources of law. Islamic law can be the material source of law, which are the sources of formal law and regulation. Islamic law together with other sources of law is used in forming national law and regulation.

\section{Arguments Supporting Implementation of Islamic Criminal Law}

The proponents of Islamic criminal law implementation have several arguments, among them are: 
1. Since Islamic criminal law is an integral part of Islamic religion, implementing this law is a part of religious obligations (particularly for Muslims) and the implementation of religious obligations (ìbādah) is protected by the Constitution. ${ }^{28}$

2. There is some disappointment towards the existing criminal law (Indonesian Penal Code and criminal provisions in many statutes) which cannot prevent the spread of criminal conduct in this country. ${ }^{29}$

3. There is an idea that the application of Islamic criminal law can decrease criminal rates in Indonesia. ${ }^{30}$ The deterrence effect and decrease recidivism rate are also arguments for implementing Islamic criminal law.

\section{Arguments against Islamic Criminal Law Implementation}

Even though the majority of Indonesian people are Muslim, the opponents of Islamic criminal law remain dominant. The arguments against its implementation include the following:

1. There is an idea against formalization of Islamic teachings. What is more important is not to implement it textually but to take the spirit of Islamic teachings and principles for the good of the people. There is also an argument that implementing Islamic Sharī'ah through local regulation would deteriorate Islamic values. $^{31}$

$28 \quad$ Chaider S. Bamualim, et.all, Radikalisme Agama dan Perubahan Sosial di DKI Jakarta (Radicalisation of Religion and Social Change in Jakarta). The Language and Culture Research Team of Jakarta National Islamic. Jakarta, 1999/2000.pp. 4-5. This is supported by Indonesian Hizbut at Tahrir in many publications and events. Foreword of Ma'ruf Amin, chairman of Indonesian Ulama Council in MUI,s national conference, Jakarta, 6/11, quoted in erasmuslim.com. Hasyim Muzadi, Tempo (29 Juli 2006), see also “Azyumardi Azra: Perda Syariah Reduksi Nilai Islam” (www.csrc.or.id, Juli 2007). 
2. There is no need for criminal provisions based on Islamic Sharī ah since there are already many criminal provisions in place within Indonesian Penal Code. The important thing is how to implement those provisions consistently. ${ }^{32}$

3. There is a risk of the emergence of violent and oppressive behavior toward minorities by certain groups in the name of Sharī'ah, such as the mass protest toward night clubs or religious buildings by particular groups in West Java, Bengkulu, Central Java, and North Sumatra. It was reported that in those incidents, the police officers cannot prevent such an offence. ${ }^{33}$ In Tangerang, criticism of a particular local regulation emerged because several people were prosecuted based on it, which is regarded as vague and uncertain. ${ }^{34}$

4. There is an idea that implementation of Islamic Sharī'ah violates human rights and degrades human dignity. ${ }^{35}$ The fear of the implementation is also related to the severity of the punishment as shown in other Islamic countries that have implemented Islamic Sharī‘ah.

The implementation of Islamic Sharīah (including Islamic criminal law) has been an on-going debate since the early period of Indonesian independence. In the post reformation and the beginning of regional autonomy era, there were a lot of aspirations that were facilitated in the law on regional government (Law No. 22 of 1999 and Law No. 32 of 2004). The law states that a province or a municipality has the power to create "peraturan daerah" (regional or local regulation) that accommodates specific aspirations in that particular province or

$32 \quad$ Syafii Maarif, Nahdlatul Ulama Conference, Surabaya, Tempo, (19 Juni 2006).

33 Theophilus Bela, M.A. President of Jakarta Christian Communication Forum (FKKJ), “Holy See Speaks Up for Minority Rights.” http:// www.zenit.org/english/reprinting.html.

$34 \quad$ KBR 68h report for Nederland Radio, Hilversum, 17 April 2006 13:10.

35 Ampuh Devayan and Murizal Hamzah, Polemik Penerapan Syariat Islam di Aceh (Polemic on Implementation of Islamic Shariah in Aceh), Banda Aceh: Yayasan Insan Cita Madani, 2007, p. 63. 
municipality. The regulation normally entails limited criminal sanction (imprisonment for not more than 6 month or fine not more than 50 million rupiah).

Since 1981, an expert team was appointed to develop a draft of New Indonesian Penal Code in order to replace the existing Penal code inherited from the Dutch era (1917) i.e. wetboek van Strafrecht voor Indonesie. Although the main sources of the draft were taken from the existing Penal Code, there is a statement asserting that certain Islamic criminal law norms are included in the draft. This notion, perhaps, is concluded from the fact that certain morality related offences are accomodated in the draft, such as "living together out of matrimony" or “kumpul kebo," "homosexuality," “incest," and "prostitution."36

In contrast to other provinces, Nanggroe Aceh Darusalam receives special treatment in terms of application of Islamic Sharī'ah through the Law on Aceh Government ( Law No. 11 of 2006). ${ }^{37}$ This Law provides a strong legal basis for the implentation of Islamic criminal law. "Mahkamah Syariah" (Syariah Court) in Aceh has extensive powers ("kompetensi") compared to "Pengadilan Agama" in other provinces since it also covers criminal cases (beside particular civil cases among Muslim citizens). According to Section 128 (3) of the Law No. 11 of 2006, Syariah Court in Aceh has power to receive, examine, try, decide, and settle cases that cover ahwal al-syakhsiyah (family law), muamalah (private law), and jinayah (criminal law) based on Islamic Syariah. The subsidiary legal provisions refer to Qanun (Section 128 sub section 4 Law No.11 of 2006)..$^{38}$

$36 \quad$ Muhammad Amin Suma, a leading professor at Jakarta National Islamic University (UIN) pointed out that in general the draft of Indonesian new penal code is in line with Islamic criminal law. See Muhammad Amin Suma, "Telaah Kritis Sumbangan Konstruktif Terhadap RUU KUHP” (Critical Review and Constructive Toward Indonesian new Penal Code Draft), Focus Group Discussion "Melihat Politik Kodifikasi Dalam Rancangan KUHP” (Observing Codification Politic on Indonesian Penal Code Draft), ELSAM, Jakarta, 28 September 2006.

37 The law promulgated after giant earthquake and tsunami happened (December 2005) and the MoU signing between Indonesian Government and Aceh Freedom Movement.

38 For more information regarding the process, debate, and discussion on the implementation of Islamic criminal law in Aceh see Ampuh 


\section{“ISLAMIC CRIMINAL LAW" IN LOCAL REGULATION OUTSIDE ACEH: IS IT REALLY ISLAMIC LAW?}

The Law on Local Government gives authority to provinces and municipalities to develop local regulations (Perda) and apply them according to the needs and the aspirations of their people. Such a development also applies to the policy-making process related to freedom of expression and freedom to perform religious obligation in Indonesia. Previously, particularly during Soeharto era, religious activities were under pressure from the government. ${ }^{39}$ Later, the freedom provided by the Law on Local Government gave opportunities to provinces and minicipalities to create regulations in accordance with their aspirations and their particular needs in developing their regions. In this regard, there are several regions still struggling to develop local regulations based on Shariah, which matches their visions and aspirations. Based on Law No. 22 of 1999 on Regional Autonomy (and then Law No. 32 of 2004), hundreds of local regulations were issued, and many of which were accused to be "Sharī'ah-based law."

Certain groups have accused the procedural process of "Sharī'ah-based" regulations to be undemocratic. This is due to the fact that public participation in the process is very minimal, which means that the Sharī ah implementation tends to be a closed-agenda which process is without any dialogue or participation from both muslim and non-muslim society.

It is argued that the idea of implementing sharī'ah by means of state (local government) instrument is not in accordance with the public aspiration (particularly Muslims). Therefore, the legitimacy of sharī'ah formalization through "perda" or local regulation is quite weak. ${ }^{40}$ However, such weakness is not unique to "sharī'ah-based” regulations

Devayan and Murizal Hamzah, Polemik Penerapan Syariat Islam di Aceh (Polemic on Implementation of Islamic Sharī'ah in Aceh), Banda Aceh: Yayasan Insan Cita Madani, 2007.

39 Robert W. Hefner, Islam In Indonesia, Post Soeharto: The Struggle For The Sunni Center (Indonesia: Academic Research Library, 2008), p.139.

40 http://www.kampusislam.com/index.php?pilih=news\&mod=yes\&aksi= lihat\&id=390. 
only since other "non-sharī'ah-based" regulations also posseses similar defects.

According to the opponents of those regulations, beside creating controversy, social distress and conflict, "sharī'ah-based” regulation has a high potential of being used as a means of religious politicization. When this happens such a regulation loses its religious authority, and it merely plays the role of regular public policy of the respective government. ${ }^{41}$

Most of the "shariah-based" regulations are related to daily prayers or religious activities. It is estimated that there are at least 15 local regulations which regulate the obligation to use Jilbāb or muslim dress, to stop all activities during $\bar{a} d h \bar{a} n$ (call for prayer), and to perform "puasa Senin-Kamis" (fasting done on Monday and Thursday which is a recommended action in Islam). Others regulate the ability to read the Qur'ān as a requirement to enrol into schools, to get career improvement, ${ }^{42}$ or even to get married. ${ }^{43}$ Regardless of criticism, such regulations actually result in some social advantage, such as decreasing alcoholic drinking and gambling in Bireun, Aceh after the implementation of such regulations. The appearance of "sharī'ah-based" or "moral-based" regulations drew different responses not only by people in the other regions but also by the people to whom the regulations are applied. There are at least three categories of response to the appearance of this kind of regulations. The first group consists of those who reject the implementation based on several arguments. For example, the implementation has no clear juridical ground, societal characteristic, and social diversity. The second group consists of those who insist that "sharī'ah or moral based" regulations are inevitable. The idea is based on the argument of public morality which states that, according to the Qur'ān women are moral guardians. That is why many regulations are related to women. ${ }^{44}$ The third group consists of those who do not give any response because they either ignore the topic, or think that it is not important to discuss the problem. ${ }^{45}$

\footnotetext{
$41 \quad$ “Azyumardi Azra: Perda Syariah Reduksi Nilai Islam” (www.csrc.or.id, Juli 2007).

$42 \quad$ KBR 68h,17 April 2006.

43 http://www.csrc.or.id/berita/index.php?detail=072812022748.

$44 \quad$ Jurnal Al-Mawarid, hal. 234, Edisi XVI, 2006.

45 Ibid.
} 
Notwithstanding these criticisms, the implementation of "Sharī'ah-based" regulations in several provinces or municipalities in the spirit of creating a safer society should not be seen as a danger or a threat. Not only does this approach conform to prior laws and regulations but it also represents the good intention of the local governments to protect their public's morality and to adopt religious principles. A critical problem may emerge if the awareness of the "Sharī'ah-based" regulations implementation is poor, and it does not involve participation from the society.

\section{ISLAMIC CRIMINAL LAW IN ACEH}

The only province which formally applied Islamic criminal law is Aceh. Known as Serambi Mekah and front gate for Islam, Aceh has long history of implementing Sharī'ah. ${ }^{46}$ Significant changes and political configuration have occurred since the stepping down of Soeharto, the Habibie era, the Abdurrahman Wahid government, the Megawati regime, and continues to the present Susilo Bambang Yudhoyono period.

After the Memorandum of Understanding which symbolizes the peace process between Indonesia and GAM had been signed in Helsinki, Aceh drafted a new legislation (Law No. 11 of 2006 on Government of Aceh). The legislation covers the existence of Mahkamah Syariah (Syariah Court) and Islamic Law. Based on the new law, the Syariah Court in Aceh has broader role compared to Religious (Islamic) Court in other provinces. In addition, the new law also recognizes Islamic criminal law (jināyah) as object of the Syariah Court. Jināyah and its law of procedure are governed and regulated in Qānūn. ${ }^{47}$

$46 \quad$ Ayang Utriza, a lecturer at the faculty of Law and Shariah, National Islamic University of Jakarta is of the view that Aceh Kingdom (Kesultanan) claiming to be running an Islamic government system is only using adapted law to govern and regulate its people. It is not Islamic law as recent common perceptions continue to indicate. See Ayang Utriza, "Hukum Adat vis-a-vis Hukum Islam di Aceh: Tinjauan Sejarah Hukum di Kesultanan Aceh tahun 1516-1688 M" (Adat Law vis-a-vis Islamic Law in Aceh: A Legal History in Aceh Sultanate 15161688), Jurnal Hukum \& Pembangunan, Year 38 No. 2, April-June 2008. Mark E. Cammark, Review Essay: "Discovering: Islamic Law" (Indonesia: Academic Research Library, 2009), p.168. 
In the light of this new legislation, it becomes possible to apply Sharī'ah law in this province. Aceh has a long history related to Islam. Almost every village or gampoeng in Aceh has meunasah or mosque, where children learn al-Qur'ān and Islamic teachings from an early age. They learn what things are allowed and are prohibited in Islam. That is why the concept of Qānūn is well recognized. However, the disemination of Qānūn substance is still very essential for them to develop legal awareness.

There is still a debate whether it is necessary to apply Islamic criminal law in the present situation. Is it important to use Sharī'ah for local institution, agency or bureaucracy which are in fact formed by humans and applied according to their own interpretations? On the other hand, certain unpopular bureaurcratic policies which still get implemented in the name of sharī'ah which actually assert a "magic power" in reducing people's rejection, ${ }^{48}$ ought to be reviewed.

Legal ground for Islamic Sharī'ah and Shariah Court in Aceh are:

a. Law No.11 of 1999 on Implementation of Aceh Special Province;

b. Law No 11 of 2006 on Aceh Government;

c. Law No. 18 of 2001 on Special Autonomy for Aceh.

These laws, particularly Law No. 11 of 2006 provide a strong basis for the existence of Mahkamah Shariah with its broader role and jurisdicitons, which are not only Islamic private law but also Islamic public law (including criminal law). In 2001, Aceh Government created a new institution which deals with this matter, namely Dinas Syariat Islam (Islamic Shariah agency).

Those laws and regulations constitute normative grounds for the implementation of Islamic Sharī'ah in Aceh within the jurisdiction of the Republic of Indonesia as a unitary state and based on the rechstaat. The implementation of Islamic Sharī'ah makes it possible to use Sharī ah law or fiqh in Indonesian national legal system. The implementation of Islamic Sharī'ah in Aceh involves all legal institutions. It is implemented not outside 2010). 
the system, but inside the national legal system as an integral part. ${ }^{49}$ This makes the implementation of Islamic Sharī'ah in Aceh a unique case in which Islamic Sharī'ah is implemented and receives special treatment within the national legal system.

Mawardi Ismail, the Dean of the Faculty of Law, Syiah Kuala University, pointed out that the positive law/exiting law can be interpreted as the law which prevails in a certain place at a certain period of time. It has plural characteristics that are both national and local. In this context, according to Law No. 11 of 2006, Qanun Shariah in Aceh is considered as part of positive law/existing law. Indeed, Qanun Shariah may also be annulled by means of judicial review before the Supreme Court. ${ }^{50}$

According to section 128 of Law No. 11 of 2006, Islamic Shariah Court in Aceh is a part of the national justice system within Religous Court jurisdiction implemented by an independent Shariah Court. Shariah Court is a court for every Muslim who lives or stays in Aceh. This court has the authority to try, decide, and settle dispute/case covering aḥwāl al syakhșiyah (family law), mu 'ämalah (private law) and jināyah (criminal law) based on Islamic Sharī'ah. The subsidiary provision concerning these matters is regulated by Qanun Aceh.

Since 2001 several Qanun concerning implentation of Islamic Sharī'ah have been issued, among others are: Qanun No 11 of 2002 on implementation of Islamic Sharī'ah related to 'Aqïdah, 'Ibädah, Siyar Islam, Qanun No 12 of 2003 concerning Khamar (alcoholic drinks), Qanun No 13 of 2003 conccerning Maisir (gambling), and Qanun No 14 of 2003 concerning Khalwat (illegal contact/relation between an unmaried couples in a private place).

The implementation of Islamic Sharī'ah in Aceh shows a unique picture since the culture and local needs are adapted. In criminal law, for example, qișās and diyah sanction were adapted to local custom. A hundred camels can be replaced by a hundred cows or beef. In practice, qișās punishment is never implemented since the victim or the family of

49 Syahrizal Abbas, "Kerangka Keilmuan Pelaksanaan Syariat Islam di Aceh (Science Framework of Islamic Shariah Implementation” in Ampuh Devayan and Murizal Hamzah, Polemik Penerapan Syariat Islam di Aceh (Polemic on Implementation of Islamic Sharī'ah in Aceh), Banda Aceh: Yayasan Insan Cita Madani, 2007, p. vi.

50 Ampuh Devayan and Murizal Hamzah, Ibid, Polemik, pp. 52-53. 
the victim always provide afwun (pardon). Even though in diyah, the amount of 100 cows is required, in practice it is only paid with some cows.

As far as $t a^{\prime} z \bar{i} r$ is concerned, from the gampong and society leaders statement it is known that in general ta 'zìr was decided by means of musyāwarah (deliberation) among gampong leaders, and very rarely brought to the mahkamah (in the past, it only existed in uleebalang level of government or in the capital city of the Sultanate (Qadhi Malikul Adil). The punishments for $T a$ 'zir which are widely recognized are fine, admitting the fault and asking for forgiveness publicly, lashes, or exile/ banishment from gampong (the annulment of citizenship). ${ }^{51}$

$T a$ 'zìr literally means $t a^{\prime} d \bar{i} b$ or teaching. Ta'zir can also be interpreted as Al Raddu wa al Man'u which is to deny or to prevent. As remarked by Mawardi, Ta zìr is an educational sanction for a sin (crime); sanctions for such sins not covered by Sharī'ah law and uli al amri (the ruler) has the power to make a decision on it. ${ }^{52}$ Beside that, another characteristic of $\mathrm{Ta}^{ } \mathrm{z} i \mathrm{r}$ is ${ }^{53}$ the variable nature of its punishment. In other words, the punishment has not been determined by Sharī'ah and it has the minimun as well as the maximum limit. The determination of the punishment belongs to the uli al amri (the ruler).

\section{THE FUTURE OF ISLAMIC CRIMINAL LAW APPLICATION: THE PROMOTION OF TA'ZITR CRIME AND PUNISHMENT}

Regarding the implementation of Islamic criminal law in the modern context, there was a research conducted by Rudolp Peters. The research was published in the form of a book, entitled Crime and Punishment in Islamic Law, Theory and Practice From the Sixteenth to the TwentyFirst Century (2005). One important issue the author raised is the dilemma

\footnotetext{
$51 \quad$ Al Yasa' Abubakar, op.cit, p. 3.

52 Abū Ḥasan Al Mawardī, Al Aḥkām As-Sultāniyah,(Musțafā Al Bāby Al Ḥalaby, Mesir, III, 1975), p. 219.

53

Ahmad Wardi Muslich, Hukum Pidana Islam (Islamic Criminal Law), Jakarta: Sinar Grafika: 2005, p. xii.
} 
faced by Islamic countries in deciding either to apply or to eliminate Islamic criminal law. In the conclusion of his book, Peters said:

"It is precisely this ideological element that creates an obstacle to legal changes. Abolishing Islamic criminal law after it has been introduced is regarded by many as religiously forbidden, and doing so would seriously undermine a regime's legitimacy. However, if left as it is, the newly introduced law will pose some problems in the domain of compliance with the internationally accepted human rights standards. Most countries that have enacted Shari'a penal codes are the signatories of the main human rights conventions. Yet, these new Shari'a penal codes violate the human rights principles on a number of aspects. Since the abolition of Shari'a criminal law in the countries where it has recently been introduced is not an option, the solution must be sought within an Islamic framework, for instance by reinterpreting the textual sources or by referring back to the abundance of opinions found in the classic works on jurisprudence with the aim of selecting those that are most suitable with the demands of modern society." 54

In this regard, we can refer to Michell's statement which was quoted from Hasan Al-Banna, Sayyid Qutb and Abd al-Qadir 'Awda (1969, 240-1) that provides an approach to this issue: “...suspending the implementation of hadd law until there is an Islamic society based on social justice that has eliminated poverty, and its wants and is ruled by a just Islamic goverment." The argument behind this approach is that "it would be unfair to punish a thief with amputation if he were driven to theft by poverty and hunger or to apply the fixed penalty for unlawful intercourse if the doer lacked the financial means to enter the marriage institution." 55

As stated earlier, more attention is paid to Hudūd and Qiṣas offences, rather than $\mathrm{Ta}^{\prime} \mathrm{z} i \mathrm{r}$ offences. In the modern context, we may 
encourage studies on specific issues, such as the law of evidence under Islamic criminal law. We may propose a question related to the use of modern evidence (for example DNA, ballistic, forensic, internet document, audio surveillance, etc): can such evidences be accomodated by Islamic criminal procedure or not?

So far only a limited amount of studies have been undertaken on Ta 'zir offences. One criticism toward Islamic criminal law is that the law is regarded as traditional and cannot be applied in the modern era; hence, it cannot fulfill new aspirations and does not match the more developed society. This conclusion, perhaps, is based on the narrow approach to Islamic criminal law. We need to consider that $\mathrm{Ta}$ 'zir crime constitutes the majority of all crimes in Islamic criminal law (covering many other offences) compared to Hudūd and Qiṣass which cover only twelve crimes. ${ }^{56}$

The punishment applicable to Ta 'zir offences can be developed further to fulfill people's aspirations as long as they are derived from the principles of Islamic Sharī'ah. Ta 'zìr offences comprise all offences which are not part of Hudüd and Qișās offences. The legal basis of Ta ${ }^{\prime} z \bar{r}$ category is $\operatorname{Ijm} \bar{a}^{\text {r }}$ (consensus) which is related to the rights and power of Islamic state to regulate and criminalize all improper conduct that cause physical, economical, political, financial, and moral destruction to the aggrieved parties or to the society as a whole. ${ }^{57}$

This approach, however, may not resolve the debate between the human rights activists and the proponents of Sharī'ah implementation. As observed earler, Alfitri proposed strict application of Islamic criminal procedure in order to prevent the severe punishment which is seen as torturous, cruel, inhuman or degrading by the human rights standards (as writen in ICCPR and CAT). By using Islamic criminal procedure very strictly, it will be almost possible to implement the hudud punishment.

Another consequence of using Alfitri's approach is that as long as all the requirements prescribed by Islamic criminal procedure for

56 According to Muhammad Amin Suma, op.cit., many provisions in the draft of Indonesian new Penal Code may be categorized as ta' zìr crime. Different with ḥudūd and qișạs crime which are dogmatic in nature, ta 'zìr crimes/ punishments are more dynamic. In terms of punishment, the determinations can be made by uli al amri or special authorized institution.

57 Sanad, op.cit, p. 63. 


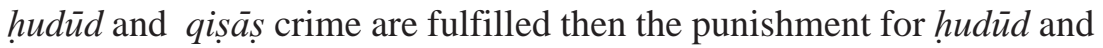
qiṣās have to be applied. In reality, hudüd and qiṣās punishment still cannot be applied, even if all the requirements in Islamic criminal procedure have been fulfilled.

To resolve this problem, in practice, there will be a sort of compromise and moderation which is in the form of "inconsistent application of Islamic criminal law" or "non comprehensive implementation of Islamic criminal law." On one side, the law prohibits all behavior considered as crime in Islamic law (including huudüd and qișās crime); however, the punishment applied for these cases is not hudūd and qișăs punishment. The punishment should be adapted according to what people are willing to tolerate or accept. The application of islamic criminal law should be reconciled with its implementation in a way that reflects social norms and values of the society. People may tolerate imprisonment, fine, community service order, or even whipping. But, they may not accept stoning.

The effort to strictly and consistenly apply Islamic criminal law punishment (as dictated by sharī'ah law) has been tried, but failed. In 2009, a draft of Qanun Aceh on Jināyah was passed by Aceh local parliament (DPRD Aceh). This Qanun governed almost all crime classified as jināyah, including a provision on "rajam" or "stoning" for zinā (adultery). The Qanun became the object of much criticism, not only from the central government, NGO activists and experts, but also from Aceh government itself which denied having signed the draft. The strongest argument behind the rejection was the fact that rajam or stoning someone to death being considered cruel, inhuman, and degrading punishment; and therefore it is against human rights and the higher laws in Indonesia.

However, not every corporal or capital punishment was rejected and unimplemented. There were several Qanun entailing corporal punishment, such as whipping, which had already been in place before the debate over Qanun jinayah happened. In 2003, Aceh government issued three Qanun that accomodated Islamic criminal law: maysir (gambling), khamr (alcoholic drunk), and khalwat (non-married couple meeting in private places). ${ }^{58}$ The punihsment for those crimes, among 
others is whipping. Even though previously that kind of punishment was criticized, it is continuously applied, and there is no massive protest or criticism against it.

In conclusion, it is submitted that one kind of "mediation" or middle way adopted in implementing Islamic criminal law is by moderation or modification of its punishment. A kind of punishment which is suitable to do the job is ta 'zìr since it is not determined in the Qur'ān or Hadìth and can be determined by a judge or a ruler. In other words, as long as ta 'zir crime or ta 'zir punishment is applied, the rejection or criticism will be minimal; thus, it can be accepted even though the model of punishment is different from those that are already written in section 10 of Indonesian Penal Code (as a general criminal law). However, from fiqh or Islamic jurisprudence, the question whether this approach (of moderating the punishment) is acceptable still needs to be answered. 